\title{
ZAKAT AS SOCIAL FUNCTION OF SHARIAH BANKING RELATED TO SMES EMPOWERMENT FORPOVERTY ALLEVIATION
}

\author{
Mispiyanti ${ }^{1}$, Junaidi $^{2}$
}

\begin{tabular}{l}
\hline${ }^{*}$ Affiliation: \\
${ }^{1}$ STIE Putra Bangsa, \\
Kebumen, Indonesia, \\
mispiyanti@gmail.com \\
${ }^{2}$ Sekolah Tinggi Ilmu \\
Ekonomi Muhammadiyah, \\
Palopo, Indonesia.
\end{tabular}

Palopo, Indonesia.

\begin{abstract}
:
Corporate Social Responsibility(CSR) is no longer a voluntary action. It already has became an obligation.Moreover, for syaria monetary institution which bases it principals on, not only morality and ethics, but also religion and spirituality. The object of this research are: BMI bank of Indonesia, BIMB bank of Malaysia, ADIB bank of UEA, and Al Baraka bank of Bahraen. It based its data on 2013 -2014 annual report. The research uses content analysis to analyze the bank's zakat and itsrelationto the degree of poverty alleviation. The results are: 1) BMI and BIMB banks did their social function in terms of people basic needs, while 2) ADIB and Al Baraka banks also did their role, in terms of recognition development and human resources development. Implementation of CSR for each bank and the state can be different according to the conditions, needand problems which faced by their people. CSR implementation could be relative because each state has a different focus, it could be some required activities for BMI and BIMB
\end{abstract}

Key words : CSR, ISR, Content Analysis, Financial statement.

\section{INTRODUCTION}

In Islam, wealth, and property are part of a deposit from Allah. One of them is the name of Allah is al-Razzaq (The great Giver) and everything that will be given by Allah, and it will be back to Allah. Therefore, whatever we have had for short-term life and all trials that we face has been prepared by Allah agree with one of the name of Allah is Al-Razzaq. In order to circulation and turndown of economic growth are staying occured, the Islamic bank as syariahbased financial institution in implementing the exchange of goods and services through trade (Tijara) and investment (Istithmaar), and the other is charity (zakat).

Zakat (Charity) is one of the Islamic pillars which have important goal, not only as a religious obligationfor muslims, but also the most important thing for social-economic purposes. By the instrument of zakat as the command of Allah to all Muslims sharing with other Muslims, 
particularly those who need than satisfy the primary needs but to satisfyworking capital for people who are difficult to access working capital.

Islamic banks as Islamic financial institutions should be able to help in process of the distributing zakat (charity) to the people who have micro enterprises and other sectors in order to reduce the level of poverty in a country through corporate social responsibility program which becoming obligatory program for banks.

The purpose of this study is to analyze zakat (charity) as a specific social function of Islamic banks relating to empowerment of SMEs with poverty alleviation purposes. Result of this study is theoretically expected to contribute ideas about charity as a social function of Islamic banks particularly related to the empowerment of SMEs with poverty alleviation purposes. Result of this study are expected to contribute practical ideas towards the problem solving of poverty issues which faced by each country through proper zakat (charity) management program.

\section{LITERATURE REVIEW}

Corporate Social Responsibility (CSR)

Carroll (1991), described CSR as a pyramid, which is composed of economic responsibility as its foundation, then legal responsibility, ethical responsibility and philanthropic responsibility are at the top of pyramid. Economic responsibility is to obtain the profit for continuity of the company. Then as a manifestation of corporate social responsibility in the sector of law, the company must comply with applicable law as a representation of rule of the game. Furthermore, social responsibility should also be reflected in the company ethical action, and reaching to philanthropic responsibility which requires companies to contribute to their community.

This is in accordance with Freeman's(1984)and Elkingtonopinion(1997), who stated that besides shareholders, there are other stakeholders who all have the right to be considered in the company management. The company does not only pursue profits (profit), but also get involved in satisfication of the public welfare (people) and participate actively protecting the environment (planet) or it is better known as the principle of Triple Bottom Lines (3P).

According to Sayyid Qutb, Islam has principle responsibilities are balanced in all its forms and scope. In the meanwhile, body and soul, individual and family, individual and social, and a community with other communities. Social responsibility refers to company's obligations to protect and contribute communities in which they are.

Yusuf and Bahari (2012) revealed there are fundamental differences between concept of the CSR in conventional perspectives and Islamic ones. CSR in Islamic perspectives must be in accordance with the Qur'an and Sunnah. Then, principles of the company system has a broader scope in syariah financial system are compared to the conventional financial system by including religion elements (Abu-Tapanjeh, 2009).

According to Haniffa (2002), social concept for Islamic banks is based on Ummah principle, trust and $a d l$. The concept emphasizes to the importance of sharing and helping to people in performing charity, waqf and Qard Hassan which aim to increase economic growth and help to solve social problems in society (Maali et al., 2006, Othman and Thani, 2010). 
According to Ayub (2007), the main purpose of Islamic banks is to create happiness and welfare Muslims, reduce inequalities of wealth ownership and unity between economic activity and religion. The concept of happiness in Islamic perspectives is different from the concept of happiness in positive economics (conventional). Therefore, all things that engage welfare and satisfy the main interest of human race must be in accordance with the philosophy of Islam.

Yusuf Al-Qaradawi (1969) in his book "Fiqh of Zakat"highlighted that there are manysocial problems happen in Muslim countries. By zakat (charity), they could be reduced because of the government's unwillingness resolving the problems. They are problems of the differences between rich and poor, begging, envious and broken relationships with others, disasters, celibacy, and refugee. According to Hameed (2007), one of the functions of Islamic banks could be used to respond those problems which revealed by Al-Qaradhawy, as Islamic banks does not only serve as a financial institution, but also it can have function as the community economic cycles through financing, both individual and institutional to SMEs.

Some studies deal with banking CSR has been developed in Indonesia, but some are rare, including study which conducted by Fitria and Hartanti (2010), found out finding of the study that conventional banking institutions generally obtained higher score than Islamic banking institutions. For Islamic banks, scoring result with GRI index is higher than ISR index.

Haniffa and Hudaib $(2004,2007)$ conducted a study of CSR Islamic banking in the Middle East by creating parameter which in accordance with Islamic principles with conclusion the awareness of Islamic banking towards CSR is still categorized low. Similar to this, Sairally (2005) stated that behavior and ethics of syariah-based financial institution managers were inconsistent.

Maali, et. Al (2006) stated social issues were less attention and did not affect implementation and reporting CSR of Islamic banks and the banks which allocated their funds for charity having act of expressing level of CSR was better, and Islamic banks generally did not reveal information that could create negative perceptions such as forbidden transaction in Islam.

According to Dusuki and Abdullah (2007), Azhar and Trisnawati (2013), the principles of CSR which in accordance with Maqasid Al-Shariah and Maslahah and CSR are generally social activities, it has appropriated the philosophy and principles of Islam. Therefore, not only profit-oriented, but also Islamic banks avoid activities and investments which are not in accordance with Islamic principles in some sectors, such as gambling, smoking, alcoholic drink also plays a role in environmental activities.

According to Othman and Thani (2010), Hasan and Harahap (2010), Kamla and Rammal (2010), in general the CSR of syariah based company is still very low and conceptual. This is due to there no standard which can be used in measuring CSR of Islamic banking. Therefore, there should be standards in accordance with the Islamic principles in measuring CSR. However, in case it is compared to conventional banking, disclosure of CSR of Islamic banking is actually better (Aribi and Gao, 2010).

Islamic Social Reporting (ISR) as the basis of CSR reporting standards AAOIFI which further developedby future researchers (Hanifa, 2002; Maali et al, 2006; Ousama and Fatima, 2006; Solomon, 2005; Othman and Thani, 2010). In particular, index ISR is an extension of 
the social reporting which includes not only the people's expectations about company's role in economy, but also company's role in the spiritual perspective (Haniffa, 2002). In addition, the ISR index also emphasizes on social justice related to reporting on the environment, minority rights, and employees.

Yusuf and Bahari (2012) showed that there are fundamental differences between the concept of CSR in conventional and Islamic perspectives. CSR in the concept of Islam must be in accordance with the Qur'an and Sunnah. While conventional CSR sometimes can not be separated from the comp interest so that the implementation of CSR be refraction. Therefore, how best the implementation and measurement of social responsibility should be based on the standards of Islamic banking in accordancewith Islamic Syariah principles.

Another study which conducted by Sofyani, et. al (2012) concluded that the whole of social performance of Islamic banking in Malaysia is higher than in Indonesia. In addition, study which conducted by Othman and Thani (2010), Ahzar and Trisnawati (2013), they concluded that the rate of ISR on company'sreportannualwhichbecame samples of the study were considered minimum. Meanwhile, Rahma (2013) concluded that the CSR disclosure of Indonesian Islamic banks can be said good, which is about $64.83 \%$ totally.

Previous studies on CSR of Islamic banks tend to analyze relationship with type of the industry, company size, composition of the board of supervisor syariah (DPS), profitability, political pressure and government, and others to broader disclosure of social responsibility (Corporate Social Reporting CSR). The development of CSR issues does not only affect conventional banks but also Islamic banks.

\section{METHOD}

Technique of data analysis

The object of this research are Bank Muamalat Indonesia (BMI) in Indonesia, Bank Islam Malaysia Berhad (BIMB) in Malaysia, Abu Dhabi Bank (ADIB) in Uni Emirat Arab, and Al-Baraka Bank (ABB) in Bahrain.

On this study, writer used method of content analysis to find out zakat (charity) and social activities and its relationship to poverty alleviation in which the syariah banks run. Kolbe and Burnett (1991) on Sekaran and Bougie's book (2010) explained tha method which systematically used to evaluate content of symbolic of all noticed communication types. Method of content analysis enables writer to analyse how much a number of information and identify systematically concerned its characteristics, such as words or wordless, concepts, characters, themes, or particular expressed sentences.

\section{DISCUSSION}

Zakat is one solution to problem of the gap between the rich and the poor who becoming the reason whyBIMB, ADIB and ABB consider zakat (charity) is very important and itsnotonly obligation and command of Allah, and as one of pillars of the Islamic law, but payment and management of zakat (charity) should be uncovered. It is different thing for BMI in which payment of zakat is only an awareness for syariah banks and government is not too strict supervising them, what it is strictly supervised in Indonesia is tax payment to the state. Not all 
banks were becoming samples which revealed comprehensively about management of zakat, no disclosure concerning zakat comprehensively on annual financial report of Islamic banks containing two possibilities, the company had paid zakat but it did not disclose on the report of Islamic banks or Islamic bank did not pay zakat because it assumed that an obligation to pay zakat is the duty of each employee and shareholder who is reponsible for paying zakat (cahrity) based on applicable regulations. Bahrain and the UAE considered zakat is an obligation of individuals and its payment is directly credited from their bank accounts based on income which they earned, and for shareholders, it is deducted from profit share they obtained in accordance with the provisions of country so that Islamic banks are not too revealing about management of zakat on the annual report.

In the case of BMI, there was comprehensively no disclosure of zakat because it was managed by external institutions of the Islamic banks that a foundation, that is Baitulmaal Muamalat (BMM) which is the affiliation of Bank Muamalat Indonesia (BMI) and a representative of the bank to collection and distribution of Zakat, Infak, Sedekah (charity) (ZIS), with social responsibility of BMI through micro-enterprise development program for social activities. Nevertheless, BMM is an external institution of BMI, but all funds and activities of BMM are conducted under BMI's. Forsupervisidetailed explanation about the management of zakat in the banks which studied as follows:

1. Bank Muamalat Indonesia (BMI)

All funds which received by BMM, they are zakat (charity) and non zakat (charity) distributed in social programs and economic development to community through programs which have been continuous implemented every year. The programs which established by BMM focuses on three parts, as follows :

a. Community development, that is programs which associated with increased capability improvement and public service in physical sector.

b. Islamic socialization is a program which provides for increasing of the public understanding of Islam and its infrastructures.

c. Micro financing, that is community economic development and partners for BMI in order to be more advanced in its business development.

\section{Bank Islam Malaysia Berhad (BIMB)}

Malaysia has implemented zakat (charity) as a tax credit in calculating personal income tax completely in the rule of Income Tax Act 1967, which was revised in 2006, Malaysian government included zakat (charity) into Part II imposition and General Characteristics of The Tax in Section 6A Subsection (3) which contains the Tax Rebate. Thus principally, the tax laws in Malaysia, noted that zakat is a discount or a deduction to payable income tax including zakat fitrah (charity) and other obligations which paid by muslims, as long as there is evidence removed by special institution which handles about the zakat (charity). Zakat (charity) at Bank Islam Malaysia Berhad (BIMB) is one of the essential elements. This is due to Islamic financial institutions of BIMB collecting zakat (charity) from the profits and its employees, and being responsible for public in social activities, religious activities and community economic development throughout Malaysia regularly, even zakat funds are also used to education 
development in research and giving scholarships. Distribution of zakat in BIMB was directly conducted in social activities throughout Malaysia. In addition, BIMB also played an important role in education development, especially for children who are less fortune in all countries. As Islamic institution, the Bank had allocated a large amount of zakat funds to schools and other religion institutions, social departments and mosques in Malaysia.

\section{Abu Dhabi Islamic Bank (ADIB)}

Although United Arab Emirates (UAE) adopted system of International Financial ReportingStandards (IFRS) in managing its financial system, specifically for zakat calculation, ADIB adoptedsome methods which used by AAOIFI. It is based on statement that the method of zakat (charity) calculation goes to the rules which issued by AAOIFI and fatwa given by Syariah Supervisor Board.

The existence of economic growth and the rising profit share which received directly affects level of the zakat (charity) payment in ADIB and its realization of zakat payments immediately increase every year. Zakat (charity) is used to defray activities and it is directly proportional in development and improvement of the results.

Although UAE is one of the countries with its population prosperity level is relatively high and it is one of the countries whose economies are fairly advanced and stable to the crisis, but type of the zakat distribution which conducted by ADIB tends to be social and religious activities.

\section{Al-Baraka Bank (ABB)}

The management party does not participate in managing zakat as zakat payment is regarded as an individual responsibility and it is entirely delegated to each employees and shareholders using method of the zakat payment which is directly credited for saving and amount of the profit shares which they received. Management of zakat fund is entirely becominggovernment responsibility. It is stated by Al-Baraka Syariah Supervisor Board in a statement.

Social Responsibility and social activities

Social responsibility is one of duties of Islamic banking. However, if the Islamic bank has not revealed its social responsibility well, it does not mean that Islamic banks do not perform its social responsibility. It could be the Islamic bank has made its social responsibility but it is not disclosed in detail on the annual report and it can be caused by government conditions, social and community in which the Islamic banks run that makes its social activities are different.

1. Bank Muamalat Indonesia (BMI)

In accordance with conditions of Indonesian people, focus of the CSR activities of Bank Muamalat Indonesia (BMI) through Baitulmaal Muamalat (BMM) in the community development sector, microfinance and religious social assistance. In performing functions of its social responsibility, BMI-BMM creates programs within scale and various particular purposes among each programs, as follows: 
a. Baitulmaal Muamalat empowerment program

Baitulmaal Muamalat empowerment program (BMM) in economic empowerment, especially in microeconomics, is one of aspect that concerns Baitulmaal Muamalat. This commitment is embodied in Muamalat Micro enterprise community program of mosque based (KUM3), community syariah financial cooperation of Muamalat Micro enterprise of mosque based (KJKS-KUM3) and Syariah Micro Financial Institution (LKMS).

KUM3 program is a program providing circulated funds for productive enterprises to micro entrepreneurs who come from poor families. The participants are worshipers who live around the mosque. The program aims to improve the quality of life.

Community syariah financial cooperation of Muamalat Micro enterprise of mosque based (KJKS-KUM3) is a formal financial institution which was established through the empowerment of Muamalat Micro enterprise of mosque based. This program is ongoing. KUM3 program in one area where has included period time for maximum two years. These areas can be directed to perform independence in legalization of funds ownership.

One of commitments of Baitulmaal Muamalat in developing micro-enterprises in Indonesia has been demonstrated in the empowerment and development of Islamic Microfinance Institutions (LKMS). The program is intended to help, emerge and strengthen institutions of the Islamic microfinance through capital supply, mentoring, training, technology support and others. Up till now, the empowerment and development LKMS program has been jointly conducted with partnership institutions including the Ministry of Cooperation and Small and Medium Enterprises of the Republic of Indonesia (Ministry of Cooperation and SME). By means of this program, people are expected to be more independent economically, powerfull in performing work.

b. The annual program of Baitulmaal Muamalat

As the institution which manages public funds in ZIZ BMI-BMM has regular annual program which is held on every Islamic religious holidays such as Eid and Eid al-Adha. Implementation of social activities is conducted by BMM based on ZIS funds (Zakat, Donation and Charity) of Bank Muamalat, employees and customers, CSR funds, and other social funds based on BMI external parties, and non-halal funding received by Bank Muamalat, such as income as a source of placement of the funds in conventional banks.

c. Empowerment Programs

Baitulmaal Muamalat also utilizes zakat (charity), infaq, and charity (ZIS), which have been mandated to Baitulmaal Muamalat. Amanah funds are utilized in education and social sector. One of manifestation of BMM's attention towards education in giving scholarships and ongoing coaching to talented orphans.

Compensation is a zakat (charity) distribution program for mustahik who needs. Compensation can be given in educational assistance, health, social, and humanitarian.

Muamalat Response Action (ATM) is a humanitarian program to help victims of natural disasters, such as earthquakes, floods and so on. The provided assistance is discontinues and sustainable assistance. The victims do not only need instantaneous assistance after getting disaster which happened to them, but also they need ongoing assistance to restore their economic and social conditions after the disaster. 
Besides social activities, BMI-BMM also has Muamalat Healthy Community program which is an innovative program of Baitulmaal Muamalat (BMM) in social compensations, such as health service for the poors.

d. Empowerment programs, special programs.

Baitulmaal Muamalat also has special programs in education sector for orphans who are victims of tsunami disaster in Aceh. This is due to one of the shareholders are foreign parties, BMI also distributes CSR funds from foreign parties which reported on the financial report in 2012-2014.

\section{Bank Islam Malaysia Berhad (BIMB)}

Programs and BIMB social activities is almost similar to what it was practiced by Bank Muamalat Indonesia (BMI), that is small economic empowerment, education and social activities based on Islamic principles and reveal additional CSR activities every month. By improving standard living and people welfare in the area where bank runs, the chosen focus of BIMB was to participate for improving people's standard living who need helps in education sector through a program called "SMART", social activities and capital supply for the poor and SMEs and health. BIMB also encourages all employees and their families to participate for helping the poor to improve their standard living.

In addition to "SMART" program, one of BIMB a poor, by ongoing teaching and learning activities, assistance is also provided in some facilities and infrastructures. BIMB participates in advancing education in Malaysia cooperating with several universities, and one of them is University of Technology MARA (UiTM) in giving scholarships.

Implementation of CSR in economic development sector aims to create community independence and achieve the increase of prosperity in long term and help to reduce poverty. CSR program is embodied in capital supply, work facilities and make them as partner for BIMB in order to be more developed.

As BIMB commitment to social and religious activities, all source of funds are used to support CSR programs consistently keep on increasing and all source of zakat funds are used to reduce poverty, education and health in Malaysia.

\section{Abu Dhabi Islamic Bank (ADIB)}

According to Arab Monetary Fund (AMF) in 2007, United Arab Emirates (UAE) is a country whose the highest and the most consumptive prosperity level in the Middle East, followed by Qatar, Kuwait and Bahrain. This occurs problem for government and population, such as the rate of divorce, obesity, which concern UAE government's interest.

Based on conditions and problems that exist in UAE, policy and CSR implementation program more focus on developing of awareness to community how UAE manages the financial well and wisely and development of society and environment in UAE as evidence that ADIB has interest for environment, community economic development in giving greater opportunity for bachelors who come from UAE working as employees of ADIB.

CSR implementation in community economic development sector in UAE aims to create self-reliance in achieving the increase of long term prosperity. CSR program is realized 
by giving capital supply, work facilities, etc. ADIB's commitment and role are to develop the ability of young generations and also provide initiatives towards community development.

CSR programs which implemented by ADIB in social, civic and religious sector were embodied in giving special assistance to Muslim community during Ramadan month by providing assistance and distributing food for them.

Detail information about ADIB's CSR activities development of community ability in education, health and sports development and realize people to get married, if they haverealized the high demand of needs and work pressure which make them being afraid of getting married, while marriage is one of Sunnah and it is recommended to do.

4. Al-Baraka Bank (ABB)

For theme of ABB's social activities do not mu report. It could be one of reason is disclosure of AOIFI standard about social activities is not a required thing, because Bahrain is one of the countries where adopts the standard which issued by AAOIFI in financial system. However, CSR activities which undertaken by ABB is not different from what it has been done by ADIB, considering the level of prosperity, problems and social issues which faced tends to social development activities and religious, and they tend to similar annual program by becoming main sponsorship. The activities are sponsoring sport and world conferences concern Islamic finance (AAOIFI) and its main focus which is not only to Bahrain's people but e world.

\section{CONCLUSION}

Globally, Islamic banks were decided to samples which implement and reveal consistent social responsibility well. Thus, it can be concluded that the banks were already decided to samples have been better than findings of the previous studies, and we are more aware of importance of the social responsibility disclosure based on Islamic principles, and they have performed their role as Syariah-based banks.

All banks which were dedicated to samples, revealed about their social activities. Most social activities of Islamic banks were dedicated to samples tend to more focus on religion, education, health sector and business development for SMEs.

The practice of social activities between BMI and BIMB is almost entirely equal, that is fulfillment of the basic needs in financial assistance to the poor, capital enterprises for SMEs and educational assistance in giving scholarships and medical assistance. ADIB and ABB's CSR implementatillthe basic needs of people but also it tend to development of greater opportunities for students from the UAE working in ADIB and ABB, and joining as activitiy funding sponsorship which is entertaining, such as sports activities.

Implementation of CSR for each bank and the state can be different according to the conditions, needs and problems which faced by their people. CSR implementation could be relative because each state has adifferent focus, it could be some required activities for BMI and BIMB, but $\mathrm{ADIB}$ and $\mathrm{ABB}$.

\section{Future Research Agenda}

For future research/study can be conducted by doing discussion on a practical review of implementation and disclosure, and its impacts of social responsibility of Islamic banks, 
by observing or even performing confirmation directly to management and DPS, and increase stretches of time and sample of banks which conducted.

It can also be conducted a comparison of the social responsibility practices of Islamic banks in other countries in different continents and ideologies, such as Pakistan, Egypt, Saudi Arabia, Singapore, the UK and others, and object of the study/research can be conducted more than one in each country. Findings of the study can certainly be used as a comparison and reference for Islamic banks to be better and more advanced in development and disclosure practices of social responsibility in order to not to give wrong conclusions about social responsibility practices of Islamic banks in each country.

\section{REFERENCE}

Abu-Tapanjeh, A.M. (2009).Corporate governance from the Islamic perspective: A comparative analysis with OECD principles. Critical Perspectives on Accounting, 20, 556-567.

Ahzar, F. and Trisnawati,R. (2013).Pengungkapan Islamic Social Reporting pada Bank Syariah di Indonesia. Proceding seminar nasional, Universitas Muhammadiyah Surakarta (UMS).

Al-Qardawi, Y. (1969).Fiqh Az-Zakah. Beirut:Darul Irsyad.

Ayub, M. (2007).Understanding Islamic Finance. Jakarta: Gramedia.

Carroll, A.B. (1991). The Pyramid of Corporate Social Responsibility: Toward the Moral Management of Organizational Stakeholders. Business Horizons July August, 39-48.

Dusuki, A.W and Abdullah, N,I. (2007). Maqasid al- Shari ah, Maslahah, and Corporate Social Responsibility.The American Journal of Islamic Social Sciences, 24:1.

Elkington, J. (1997).Enter The Triple Bottom Line of 21th Century Business.Oxford:Capstone.

Fitria, S. and Hartanti, D. (2010). Islam dan Tanggung Jawab Sosial: Studi Perbandingan Pengungkapan berdasarkan Global Reporting Initiative Indeks dan Islamic Social Reporting Indeks.SimposiumNasional Akuntansi XIII, Purwokerto.

Freeman, R.E. (1984).Stakeholder theory of the modern corporation. New York: Englewood Cliffs Prentice Hall.

Haniffa, R. (2002).Social Reporting Disclosure-An Islamic Perspective. Indonesian Management andAccounting Research, 1, 128-146.

Haniffa, R. and Hudaib, M. (2004).Disclosure Practise of Islamic Financial Institutions: An Exploratory Study. Working Paper No. 04/32, Bradford School of Management, University of Bradford, Bradford, Inggris.

Haniffa, R, and Hudaib, M. (2007).Exploring the Ethical Identity of Islamic Banks via Communication in Annual Reports. Journal of Business Ethics, Vol. 76, 97-116. 
Hassan, A and Harahap, S,S. (2010).Exploring corporate social responsibility disclosure: the case of Islamic banks. International Journal of Islamic and Middle Eastern Finance and Management, 3(3), 203-227.

Kamla, R and Hussain G. R. (2010), Social Reporting By Islamic Banks: Does Social Justice Matter?.International Graduate School of Business and Finance The University of Dundee United Kingdom Australia, APIRA.

Maali, B., Casson, P. And Napier, C. (2006). Social Reporting by Islamic Bank. ABACUS, Vol. 42, No.2, 266-289.

Ousama,A.A. and Fatima, A.H. (2006). The Determinants of Voluntary Disclosure in the Annual Reports by Shariah Approved Companies Listed on Bursa Malaysia. Paper presented at IIUMInternational Accounting Conference 3. 26-28 June 2006, Kuala Lumpur, Malaysia.

Othman, R and Azlan, M,T. (2010). Islamic Social Reporting of Listed Companies in Malaysia. International Business \& Economics Research Journal, Vol. 9, 135-144.

Sairally, S. (2005). Evaluating the Social Responsibility of Islamic Finance: Learning From the Experiences of Socially Responsible Investment Funds. The 6th International Conference on IslamicEconomic and Finance, Jakarta.

Sofyani H. et al. (2012). Islamic Social Reporting Index sebagai Model Pengukuran Kinerja Sosial Perbankan Syariah (Studi Komparasi Indonesia dan Malaysia). Jurnal Dinamika Akuntansi Vol. 4, PP. 36-46.

Sulaiman, M. (2005). Islamic Corporate Reporting: Between the Desirable and the Desired. ResearchCentre International Islamic University Malaysia. First Edition, H. 19.

Yusuf, M.Y, and Zakaria, B (2011). Islamic Corporate Social Responsibility in Islamic Banking: Towards Poverty Alleviation.The 8 th International Conference on Islamic Economics andFinance, Vol. 10. 